\title{
Research Paper: Comparative Assessment of the Sustainability of Rural Housing in the Old and New Textures of Rural Areas: A Case Study in Villages of Central Area of Kabudarahang County
}

\author{
Mehdi Pourtaheri ${ }^{*}$, Shirin Hemmati ${ }^{2}$
}

1. Associate Professor, Department of Geography and Rural Development, School of Humanities, Tarbiat Modares University, Tehran, Iran

2. MA, Department of Geography and Rural Development, School of Humanities, Tarbiat Modares University, Tehran, Iran.

\begin{tabular}{|c|c|}
\hline $\begin{array}{l}\text { Use your device to scan } \\
\text { and read the article online }\end{array}$ & Citation: Pourtaheri, M., \& Hemmati, Sh. (2017). Comparative Assessment of the Sustainability of Rural Housing in the Old \\
\hline 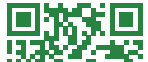 & $\begin{array}{l}\text { and New Textures of Rural Areas: A Case Study in Villages of Central Area of Kabudarahang County. Journal of Sustainable } \\
\text { Rural Development }\end{array}$ \\
\hline 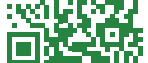 & doi : https://doi.org/10.18869/nrip.jsrd.1.1.67 \\
\hline
\end{tabular}

Article info:

Received: 13 Dec. 2017

Accepted: 10 Mar. 2017

\section{Keywords:}

Housing, Sustainable rural housing, Texture (old, new), Sustainable rural development

\begin{abstract}
A BSTRACT
Purpose: Sustainable housing can be considered as one of the important indicators of development and progress. Thus, identifying the characteristics and methods of providing sustainable housing is important. Sustainable housing is one of the basic needs which in terms of development and change in the living standards of rural areas displays varying aspects in old and new construction textures. Among the structural components of the village, sustainable housing is one of the most important ones and part of the overall identity of the village. Also, it is the illustration of functional integrity of the village texture. It seems that by passage of time, it has seen the most changes, which have caused a gap in the functional integrity of the structural texture of rural habitations. Therefore, the present study by using physioenvironmental, physio-economic, and physio-social indicators, has assessed the sustainability of rural housing in the old and new structural textures in the villages of the central area of Kabudarahang Country. We tried to find out that with regard to the transformation in housing construction and structure, whether there is a significant difference between the sustainability of the old and new construction textures (sustainability of new and old housings).
\end{abstract}

Methods: 10 villages and 300 households, including 150 households living in the old construction texture with traditional and old housing and 150 households of the residents living in the new construction texture with new housings were assessed separately.

Results: The obtained results indicate a significant difference between old and new housings with regard to housing sustainability.

Conclusion: According to the analysis of responses given by households to questionnaires distributed among them, in the three dimensions of physio-environmental, physio-economic, and physio-social, the housings with old textures (old and traditional housing) possessed more sustainability degree compared to the new structural textures (new housing). 


\section{Introduction}

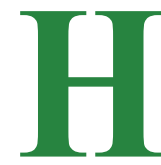

ousing is the most complex tangible phenomenon, effective in the human evolution in the context of human culture. On the one hand, its fabric is linked with issues related to natural environment, means of livelihood, forms of production, the evolutionary process of social life and technical strength (the level of economic tools and facilities throughout the history), and on the other hand, it has a unique design due to artistic aptitude, social criteria, family and kinship foundations, traditions and opinions, inner thoughts and beliefs in every corner of the Earth (Karimi, 1990: 144). In other words, housing is more than just a physical shelter, but includes all public services and facilities required for human life. It should also provide a relatively long and ensured right of possession for its users.

The primary important aspect of housing is the need for shelter. Shelter like the food and clothing is a basic and universal need and people no matter how poor they may be, should, in one way or the other, possess it. Residential unit is the core of family life and should have sufficient space for food (preparation, consumption, and storage), sitting around together, sleeping, as well as individual activities such as performing duties, recreation for children, and other basic activities of family members. Residential unit has direct effect on issues such as work productivity and family stability.

A sense of pride and attachment in the family housing unit and the feeling of conformity with it, is one of the important factors of family solidarity and stability. Although it is quite subjective, many studies has shown its importance in relation to the well-being and social cohesion of the society (Mukhber, 1984: 181). The obviousness and importance of housing become more objective when its dominant role is noted in all elements of rural texture. Housing is the main constituent of the rural context. The configuration of main components of a village such as the collection of buildings, gardens, farms, bridges and roads, open spaces such as threshing floor, the cemetery, the shrine building and main elements of the environment such as rivers and springs have significantly changed in recent years in a way that the appearance of rural communities of Iran has changed remarkably.

In the meantime, in line with the developments in the construction of rural housing developments, which its manifestations are seen in both old and new structural textures with traditional and new residences, the necessity of attending to sustainable rural housing through comparing housing sustainability in the old and new structural textures, has found significant importance, because most of the structural texture of a village are composed of its residential places (Rezvani, Nazari, \& Khorasani, 2010: 59).

Because of the functional nature and response to human needs, public activities, production elements and the environment, the rural architecture of Iran constitutes a homogeneous and organized complex with certain physical identity that is a manifestation of relationships, functions, and the multi-functional role of the spaces (Sartipipour, 2005: 29). Housing in every village with any geographical longitude and latitude or at any point in history, has taken shape based on different factors and despite similar appearances, has significant differences, too. Rural housing architecture indicates that its constructors have considered the ecological, structural, cultural conditions, and so on and acted upon building their residence based on recognition of the above mentioned and suitable integration. The traditional model of rural housing is a reflection of local requirements in its general sense. However, the new housing models in rural areas lack those characteristics.

What has taken shape in the new rural housing, in the standard or systematic form and with participation of relevant foundations and organizations is an entity without identity. Disregarding environmental conditions in the new constructions in rural areas leads to two obvious results: 1) ecological incompatibility 2) lack of optimal use of available resources (Darabi, 2009: 14). Although dealing with rural housing is generally organized with the aim of eliminating privation, providing better access to welfare services and facilities, and reducing the vulnerability of housing to natural disasters, the point should not be missed that the identity and guarding the culture and tradition of villagers is an undeniable value. Considering the above issues, it can still be assumed that rural housing models which had environmental, climatic, livelihood, and cultural elements, beliefs, and social compatibility in the past, now need to be reorganized in conformity with the today's circumstances.

Topics such as improvement in the quality of construction materials, new construction methods, protection against accidents and natural disasters, especially flood and earthquake, saving energy and improving health in the area, are among the most influential factors in organizing housing plans. The housing plans that are being prepared today, despite having some housing merits, however, have not paid respect to the concept of housing. Thus, they confront with life and the surrounding environment, and in the most ideal situation, resolve their shortcomings and defects through trial and error. On the other hand, the native housing is well aware of 
the environment potential, and instead of ignoring life requirements and challenging geographic variables, take the shape in harmony with them (Sartipipour, 2011: 4).

Therefore, a convenient housing consists of a suitable residential space in which, comfort, convenient access, security, sustainability, structural durability, adequate lighting, ventilation, and proper basic infrastructure such as water supply, health and education, a healthy environment, suitable location and access to work and basic facilities as well as having a setting for growth and strengthening relationships among family members are provided to residents, and most importantly matches with the financial ability of the household (Lutfi, Ahmadi, \&
Hssanzadeh Farjoud, 2009, 32). Considering the developments had taken in rural communities of our country in recent years, addressing the issue of sustainable rural housing, in a comparative way between the old and new structural textures, has gained special importance.

Design and codification of sustainability indicators in the rural housing should be in conformity with changes and developments of rural habitations. These indicators and housing sustainability dimensions are different in every geographical location. In this regard, Kabudarahang County has been studied as the scene of such conflict. This county is located 52 kilometers northeast of the city of Hamadan in Hamadan Province.

Table 1. Research background

\begin{tabular}{|c|c|c|}
\hline Title & Author & Content and Result \\
\hline $\begin{array}{c}\text { The necessity of studying and directing } \\
\text { housing construction process in rural } \\
\text { areas }\end{array}$ & Hussein Nasr (2000) & $\begin{array}{c}\text { After examining unsuitable results of employing urban hous- } \\
\text { ing design in rural dwellings, including ignorance of climate } \\
\text { conditions, using inappropriate materials, disregarding the } \\
\text { needs of rural community, the study recommended that prior } \\
\text { to commencing any plan, necessary studies be made with } \\
\text { regard to rural housing. }\end{array}$ \\
\hline $\begin{array}{l}\text { Indicators of rural housing architecture } \\
\text { in Iran }\end{array}$ & $\begin{array}{l}\text { Mohsen Sartipipour } \\
\text { (2005) }\end{array}$ & $\begin{array}{c}\text { By defining and explaining rural housing indicators and } \\
\text { identifying its elements, the study has shown the housing } \\
\text { space quantities and qualities and the existing differences in } \\
\text { housing quantity and quality needs. }\end{array}$ \\
\hline $\begin{array}{l}\text { Indicators and components needed in } \\
\text { rural housing planning and policy in Iran }\end{array}$ & Heidar Lotfi (2009) & $\begin{array}{c}\text { Identifying and employing indicators of sustainable rural } \\
\text { housing will evolve housing in the long term and provide a } \\
\text { suitable model and the development for rural housing struc- } \\
\text { tural texture in the country. }\end{array}$ \\
\hline $\begin{array}{l}\text { Assessment and evaluation of indicators } \\
\text { of sustainable rural housing }\end{array}$ & $\begin{array}{l}\text { Ismael Salarvand } \\
\qquad(2011)\end{array}$ & $\begin{array}{c}\text { At first, the study attended to identify the most important } \\
\text { indicators and criteria defining sustainable rural housing and } \\
\text { then identified the differences in benefiting from various } \\
\text { sustainability dimensions. }\end{array}$ \\
\hline $\begin{array}{l}\text { Examining the culture and social changes } \\
\text { in rural housing in Guilan Province }\end{array}$ & $\begin{array}{l}\text { Mozhgan Khakpour } \\
\text { (2011) }\end{array}$ & $\begin{array}{l}\text { The study has considered the architectural style of old and } \\
\text { new housings with the aim of identifying the impacts of } \\
\text { cultural changes on villages and examines the independent } \\
\text { effects of cultural components on changes in the housing } \\
\text { model. }\end{array}$ \\
\hline $\begin{array}{c}\text { An analysis of vulnerability of rural } \\
\text { housing }\end{array}$ & $\begin{array}{l}\text { Eskandar Seidaei } \\
\text { (2011) }\end{array}$ & $\begin{array}{l}\text { The study has identified the type of housings so that a com- } \\
\text { prehensive knowledge is obtained about the degree of hous- } \\
\text { ings resistance in natural disasters, especially earthquake, and } \\
\text { reached the conclusion that villagers should build their own } \\
\text { houses. However, in all stages they should be assisted so that } \\
\text { the house would be in conformity with modern develop- } \\
\text { ments and be responsive to their ever evolving needs. }\end{array}$ \\
\hline $\begin{array}{l}\text { Analysis and evaluation of indicators and } \\
\text { elements of sustainable rural housing }\end{array}$ & $\begin{array}{l}\text { Muhammadsreza } \\
\text { Beshagh, Esmaeel } \\
\text { Salarvand (2013) }\end{array}$ & $\begin{array}{l}\text { In this study, for analyzing the sustainability indicators of rural } \\
\text { housing, a list of } 20 \text { indicators were examined with regard to } \\
\text { social, economic, and physical dimensions. The authors have } \\
\text { reached the conclusion that rural housings are different from } \\
\text { one another with respect to geographical and vulnerability } \\
\text { conditions. Implementing a uniform strategy in Iran rural } \\
\text { areas that have many great differences from one another is } \\
\text { doomed. }\end{array}$ \\
\hline
\end{tabular}


Based on 2011 census, more than half of its population reside in rural areas, and such high percentage for rural population is a factor for having more focus on villages of this county. In this regard, housing as the most important physical element in the village should be considered more seriously. Considering field observations and studying the history of this county, it has been observed that a great number of villages in this area have seriously suffered from natural disasters such as flood and earthquake. However, despite all these calamities, technical principles of building construction have not been observed in new residential units as they should have, and even in some instances, it seems that the old residential dwellings with respect to some of their properties have more compatibility with their geographical environment.

As such, the authors of this study decided to conduct a comparative study on new and old residential dwellings in this county. They also try to find which of the old and new structural housings are more sustainable. To find the answer to such basic question, first, the historical background of this issue based on literature texts of our country was studied and scrutinized. Examining the records of studies conducted in this context shows that those investigations were based on indicators defining sustainable rural housing rather than a comparative study of sustainable rural housing between the traditional and new residential units in the old and new structural textures. Table 1 presents some local studies in this topic.

\section{Literature Review}

Sustainability is derived from the Latin word "Sustainer" meaning support and maintenance. In this context, the term "sustainability" can mean endure, uphold, maintain, and support of a desirable situation, or conversely, avoid an undesirable situation (Saeedi, 1998: 17). The basic difference of this idea, is to manage livelihood from income and not the capital, in other words, it is the stability of the capital (Rezvani, Nazari, \& Khorasani, 2010: 91). Based on Rio Declaration on Environment and Development, human being in sustainable development is in the center of attention, and people in harmony with the nature deserve a life with health and creativity. Development is a right that should cover equally the current and future generations. Korten (2005: 68) believed that sustainable development is a process through which, members of a society by mobilizing resources and management, increase their specific and institutional capabilities in a way that conforming to their aspirations reach an excellent stage in their lives with fair distribution. Therefore, what is regarded as sustainability in this research is the durability of rural settlements. This means that if a settle- ment system has the ability to live, it should be deemed as healthy and it develops in its systemic environment (Boosel, 1999: 24). Therefore, sustainable rural development can be defined as the process of multidimensional changes affecting the rural community. Economic growth, improvement of environmental conditions and preserving humane values in equitable ways are among its important characteristics (Pugliese, 2002: 113-114).

Considering the importance of sustainable rural development, different definitions and approaches have been presented so far in this regard. Some people believe that sustainable rural development is a pathfinder for development in which, effectiveness, justice, and sustainability have been combined (Brouwer, 2004: 47). In the sustainable rural development, land is considered one of the main resources of any spatial system. Therefore, using the term "physical" has become common in this regard. Gradually, more awareness of the scope of what is referred to as physical planning will lead to change toward social, political, and economical aspects and to assimilate them with physical aspect and spatial system (Roknodin Eftekhari, Badri, Sajayi Gheydari, \& Soori, 2015: 218).

Among physical elements of a village, housing is the most important one and part of general identity of the village. Also, it is the illustration of functional integration of the village texture constituents. Furthermore, housing, besides providing one of the basic needs of life (i.e. shelter), as a saving transforms to capital and opens a very wide field of demand, which its supply has a different nature from the subject of housing as a shelter (Dix, 1995: 10). Thus, paying attention to integrated rural dwellings in which, housing is amongst the most important elements, is of particular importance. In order to preserve the structures and the villagers' residential foundations and its durability, also its culture and livelihood and production system, much research should be conducted and their scientific results should be used in rural areas (Islamic Revolution Housing Foundation, 2001: 81). The issues of sustainability and planning and designing sustainable locations have occupied an extensive part of the science and technology of modern architecture. In theoretical domain, many teachings and tenets have been presented by scientific circles, foundations, and organizations (Pourmohammad, 2015: 21-43).

Rural housing, as shown in Figure 1, through the use of local residential places affected by social changes, utilization for tourism affected by economic opportunities, and also rural investments resulting from changes in land use and migrations, directly and indirectly are affected by fundamental changes (Toyobo, Muili, \& Adetunji, 2014: 6; Mc Keogh, 


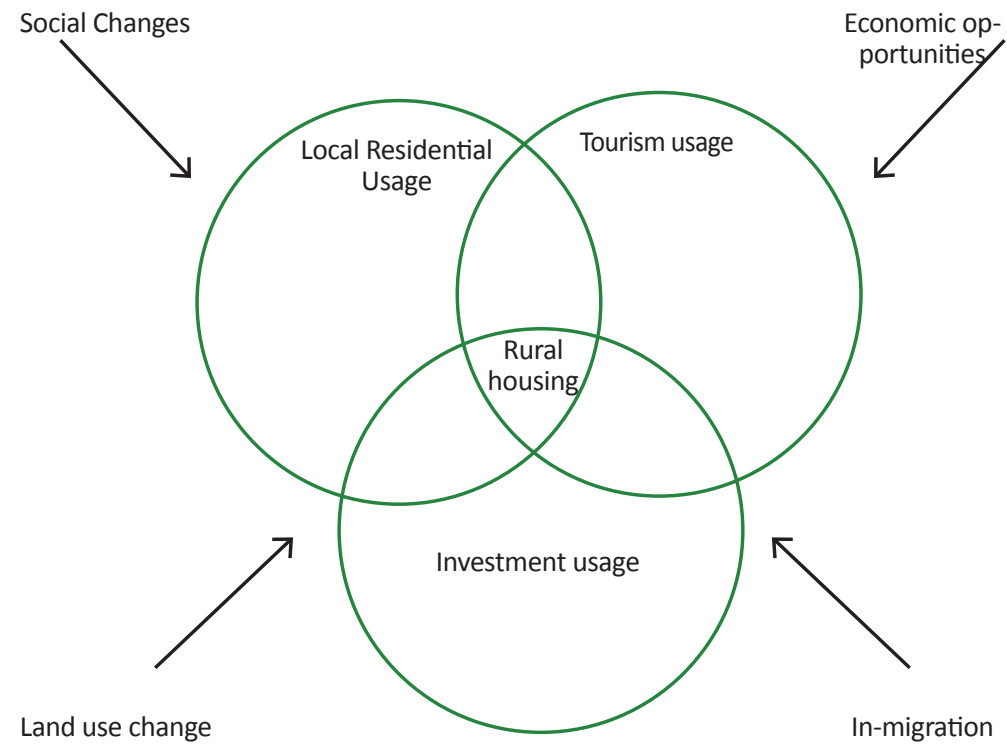

Figure 1. Dominant causes in changing rural housing

2005: 17). Sustainable construction and housing can be defined in different ways. One of the current definitions is constructions or residences with zero- impact which means not having any ecological, economical, and social negative impact (Building Maintenance Unit, 2010: 11).

Sustainable housing indicators, as fundamental tools for describing sustainability of social, economical, and physical aspects have a special role in sustainable housing planning. Therefore, development of sustainable rural housing requires identifying and analyzing various components of sustainability. Housing as a physical facility or durable economic goods can have a social role as well. Sustainable housing is defined as housing that is suitable in terms of economy, acceptable in terms of social aspect, practicable in terms of technology, and resistant and complementary to the surrounding conditions in terms of physical aspects (Shayan, Barghi, \& Agha Amrayie, 2014: 189). Sustainable housing should incorporate 5 areas of 1) conservation of natural resources (land, energy, water), 2) rational use of human made resources, 3 ) ecosystem conservation and protecting its restoration potentials, 4) observing justice among products, human beings, and categories, and 5) anticipation of health, security, and safety (Edward \& Turent, 2000: 19).

Housing is the main component of the rural texture. Meanwhile, old texture in our country includes that part of rural structural that has residential areas with organic texture. Its main materials were formed from sun-dried bricks and clay, and has high architectural and identity values. In some instances, historical textures can be enlisted among these textures which mostly had been built before 1931 . This structural texture has a particular identity and is con- sidered a symbol, a representation of the past. Often, it is located at the center of the village and its essential character is harmonious, continual, and integrated development during the course of history. In other words, over the time and based on past experiences, it has gone through its evolutionary process (Khodadadi \& Muhammadnejad, 2010: 21).

Since 1960s, the changes and evolutions in socioeconomic conditions and new technologies have accelerated in our country. As a result, a new structural texture has formed around the previous texture. In general, the evolutionary change in villages based on planning differs basically from natural evolutionary model, and is recognized as new structural texture. In this model, what is done should be based on identifying the needs, observing desirable spatial quantities (to meet the needs), approaching comprehensively toward conditions and needs and anticipating the future of rural communities.

The most important difference between the two mentioned models regarding the developments of rural textures is their use of desirable spatial quantities. Using these quantities, although may help meet the needs of rural communities, in some instances stands directly against the preferences and social interests of villagers, especially, the favorable environmental conditions. Furthermore, the composition of rural texture which is influenced by traditions and different social systems, cannot be neglected in relation to the shape of housing. For example, the previous generation, who lived with a non-modern style, carried out actions such as standing by the door, or baking bread together with neighbors. These activities were affected the shape of their housings. However, in today's generation, relations between 


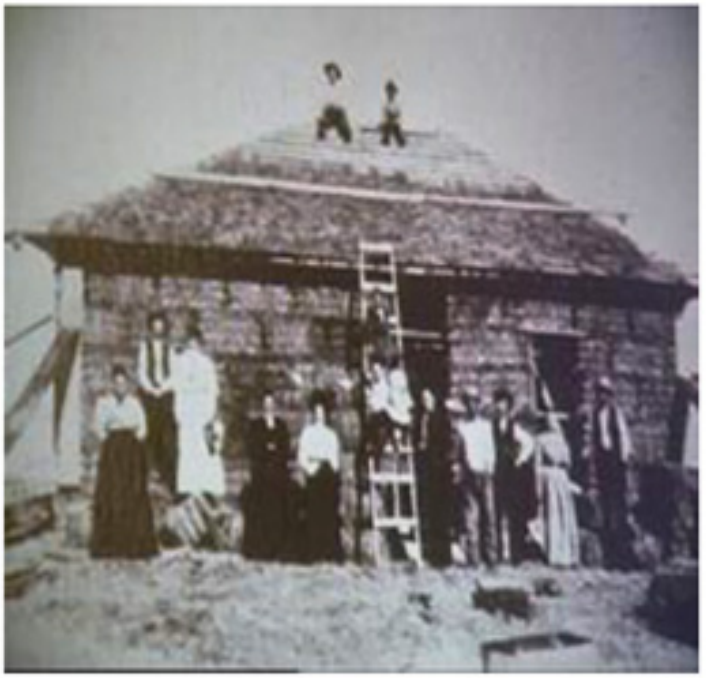

Figure 2. Old housing in conformity with environmental conditions

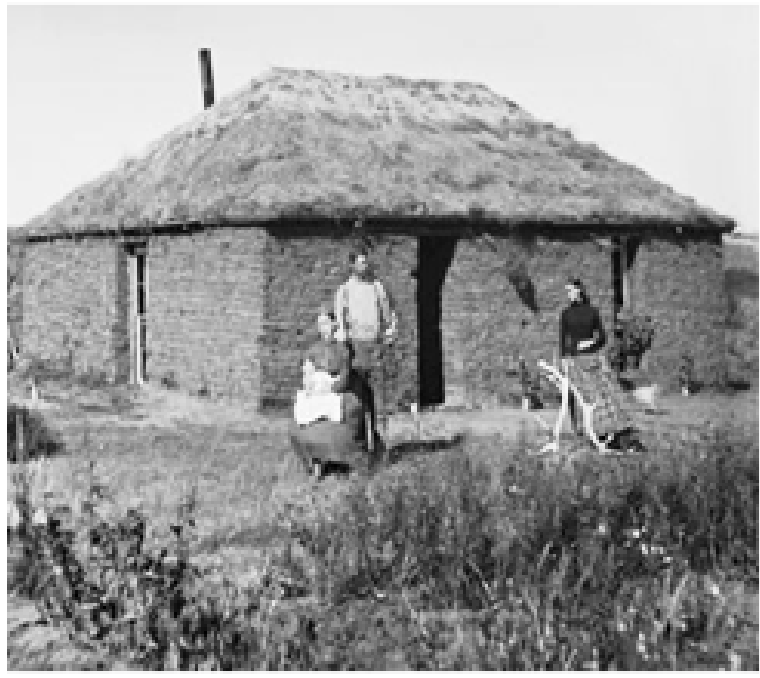

○JSR people have lessened to a great degree and the presence of mass communication devices such as TV, the radio, telephone, and so on has reduced the need for face to face communication. This in turn has impacted the shape of housings and led to increase in apartment living even in rural areas (Berry, 1980: 909).

Hence, changes in the design and construction of housing, especially rural housing, have been done without revising the mutual relation between spatial organization and style of living (Government of Bangladesh, 1997: 68). Meanwhile, many experiences in developed countries demonstrate that several changes that have taken place were in conformity with local conditions and characteristics and correspond with the living conditions of villagers. International experiences indicate that in the State of Nebraska of the United States of America, new housing construction corresponding to the old housing has advantages for residents of rural areas. New housing built with

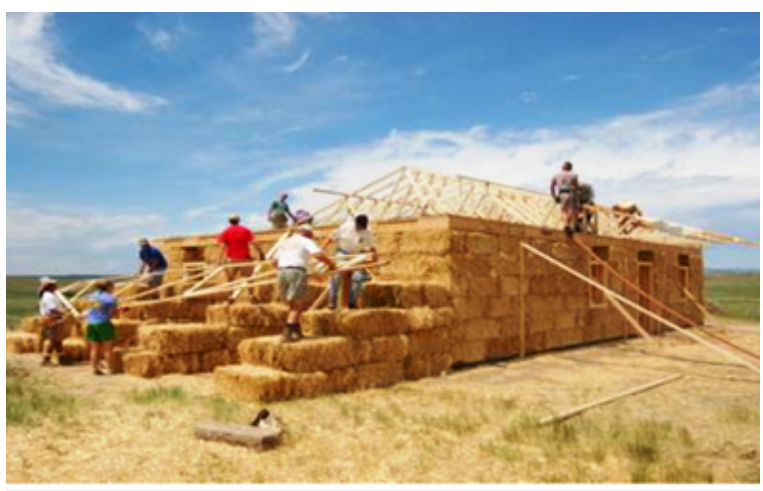

C JSRD

Figure 3. Continuing to build housing using stubble in new housing stubble lacked pollution, had insulation quality, was durable and with energy savings, low cost of manpower, and were also in line with rural community's culture. Figures 2 and 3 demonstrate these changes (Boran, 2010: 23).

Man-made environment is continually changing, and we cannot avoid interfering with these changes. Housing is a humane right. It is a process, a multidimensional and complicated one that has taken shape during the course of time and has had a special role for social groups (Andrade, Martin, \& Rodriguez, 2014: 2). In recent years in Mexico, the emphasis on these changes in housing models by transition from the traditional to new model has become the designers' subject of attention, so that a sustainable model of the rural housing with emphasis on local needs takes shape. Using native and local materials in this transition, as shown in Figures 3, 4 and 5 has been paid attention more.

Sustainable architecture, which is ecological and compatible with climate conditions offers solutions

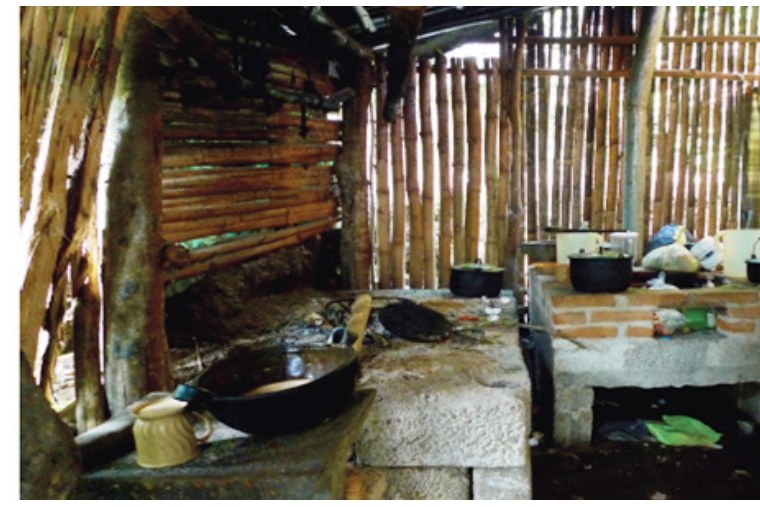

Figure 4. Housing model in the old texture 


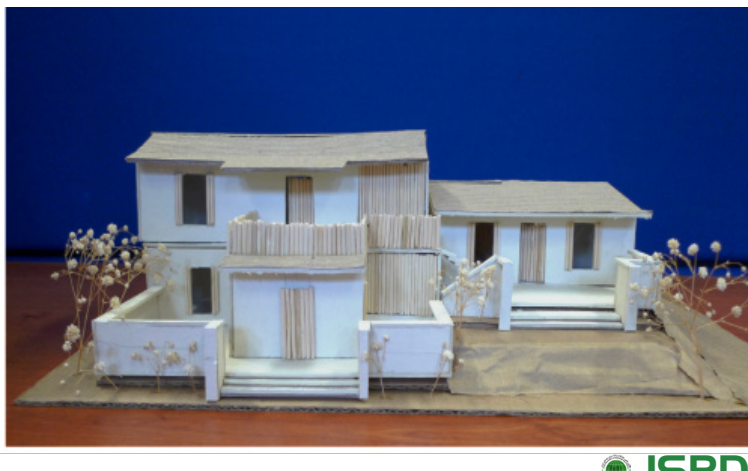

Figure 5. Recommended model in the new texture

to face challenges related to rural housing, especially energy consumption. In many old housings in India, environmental conditions, regional designs, and local durable materials in housing construction have been used. These housings are completely in conformity with environmental conditions and enjoy minimum energy consumption (Madhumathi, Vishnupriya, \& Vignesh, 2014: 302). Therefore, indicators of sustainable rural housing in line with these developments have been subject to profound transformation alongside traditional and new styles in the old and new structural textures. Obviously, one way to become aware of sustainable rural housing situation is using its explanatory indicators (Azizi, 2007: 26). These indicators on the one hand demonstrate the quantitative and qualitative situation of rural housing at any time, and on the other hand they are effective guideline to improve the planning for the future. In fact, indicators are tools for measuring and assessing the sustainability of housing, its development process, its trend of evolution, and the degree of success and realization of housing policies. Thus, besides evaluating the situation, they are used in codification of quantitative objectives of plans (Musavi \& Hekmatnia, 2006: 116). Table 2 presents some of the criteria/indicators of sustainable rural housing.

Table 2. Indicators of sustainable rural housing

Sustainability Dimensions

Criterion/Indicator/Index

1- Housing supply; 2- Number of households; 3- The need for housing; 4- Household dimension; 5- Household density in housing units; 6- Density of persons per dwelling; 7- Density of persons per room; 8- Poor housing (shed, slums, huts, etc.); 9- Average area under construction; 10Construction area per capita; 11- Housing possession (ownership or rental); 12- Housing quality regarding access to cultural-social services; 13 - Housing quality regarding health and hygiene; 14- Amount of land occupation; 15- Durability (housing quality in terms of comfort); 16- Housing quality with regard to natural disasters; 17- Housing quality regarding the building's durability; 18- Ratio of documented residential properties; 19- Duration in which residential units are used during the year; 20- Interference of work and living space; 21- Type of fuel and heating system

1- Rural housing subsidies; 2 - Ratio of housing costs to the total expenses of the household; 3 Ratio of housing costs to the household income; 4- Ratio of housing rent to the income; 5- Price

Economic sustainability of land; 6- Construction cost of one square meter of housing; 7- Different housing models; 8- The length of construction period; 9- Ratio of housing loans to total loans in rural areas; 10 - Rural areas having a bank or home savings fund

1- Housing models (structure and type of framework); 2- Construction density; 3- Occupied area 4- Residential density; 5- Average area under construction; 6- Per capita under construction area; 7- Façade and type of local materials; 8- Construction styles; 9- Age of the building; 10- Number of floors; 11- Distance to source of drinking water supply (tank-reservoir); 12- Quality of passageways and streets in terms of slope, width, and lining; 13- Use of thermal insulation

Table 3. The reliability of housing sustainability dimensions

Title

Physio-environmental sustainability

Physio-economic sustainability

Physio-social sustainability

\section{Cronbach o}

0.718

0.693

0.865 
Table 4. Criteria and indicators for rural housing physical-environmental sustainability

\begin{tabular}{|c|c|c|}
\hline $\begin{array}{l}\text { Sustainability dimen- } \\
\text { sions }\end{array}$ & Criterion & Indicator \\
\hline & $\begin{array}{l}\text { Durability of materials used in housing } \\
\text { units }\end{array}$ & $\begin{array}{c}\text { Degree of durability of materials used in the founda- } \\
\text { tions of residential units } \\
\text { Degree of durability of materials used in the ceiling of } \\
\text { the residential units } \\
\text { Degree of durability of materials used in the walls of } \\
\text { residential units }\end{array}$ \\
\hline & Durability of structures of housing units & Having anti-earthquake facilities in the residential units \\
\hline & $\begin{array}{l}\text { Application of native materials conforming } \\
\text { to the region's geographical conditions }\end{array}$ & $\begin{array}{l}\text { Laying stones in the building's foundation, utilization } \\
\text { level } \\
\text { The amount of waste in the process of housing con- } \\
\text { struction }\end{array}$ \\
\hline \multirow[t]{3}{*}{ Physical-Environmental } & $\begin{array}{c}\text { The effect of residential texture on saving } \\
\text { energy }\end{array}$ & Density of the village residential texture \\
\hline & $\begin{array}{c}\text { The effect of the residential unit's architec- } \\
\text { ture on saving energy }\end{array}$ & $\begin{array}{c}\text { The concern given to minimize and decrease the size of } \\
\text { windows and openings } \\
\text { Attention given to the setting of the housing (south, } \\
\text { southeast) to take advantage of sunlight } \\
\text { The concern given to separate the interior space of the } \\
\text { building into two parts of winter quarters and summer } \\
\text { quarters } \\
\text { The impact of the number of openings on saving energy } \\
\text { The impact of number of facades on saving energy }\end{array}$ \\
\hline & $\begin{array}{l}\text { The impact of rural residential units on } \\
\text { destruction of natural resources }\end{array}$ & $\begin{array}{c}\text { The degree of meadows and trees destruction to make } \\
\text { way for housing construction } \\
\text { The degree of green space use in housing }\end{array}$ \\
\hline
\end{tabular}

\section{Methodology}

One of the important features of descriptive research is the use of official and standard tools for data collection accom- plished by two methods of secondary data (attributive) and primary data as well as using questionnaire and conducting face to face interviews with people, through which, the needed data for research are collected. Also, referral to gov-

Table 5. Operational criteria and indicators for physical-economic sustainability of rural housing

\begin{tabular}{|c|c|c|}
\hline $\begin{array}{l}\text { Sustainability } \\
\text { Dimensions }\end{array}$ & Criterion & Indicator \\
\hline \multirow{5}{*}{ Physical-economic } & The current costs of housing & $\begin{array}{l}\text { Marginal cost for providing cooling facilities to the housing unit } \\
\text { Marginal cost for providing heating facilities to the housing unit } \\
\text { Affordability to provide for costs of taking possession of the housing unit, } \\
\text { such as rent, buy, repairs and maintenance, and so on }\end{array}$ \\
\hline & Fixed costs of housing & $\begin{array}{l}\text { Affordability to provide for costs of buying the housing unit } \\
\text { Affordability to provide for costs of building the housing unit }\end{array}$ \\
\hline & Using financial aids & $\begin{array}{l}\text { The amount of bank loans used for construction of the housing unit or } \\
\text { repair and maintenance }\end{array}$ \\
\hline & Housing supply and demand & $\begin{array}{l}\text { The amount of ground and construction sales } \\
\text { The amount of producing new housing }\end{array}$ \\
\hline & Livelihood & $\begin{array}{l}\text { The scale of residential space used for livelihood } \\
\text { The area of construction allocated to livelihood activities }\end{array}$ \\
\hline
\end{tabular}


ernmental organizations and departments to obtain needed information is another tool for collecting information. In this research, the main part of the data were collected from the questionnaire especially designed for rural household. It should be noted that these questionnaires have been distributed and collected separately in two separate structural textures, with new housings (new texture) and traditional and old housings (old texture).

The research validity was based on face validity resulting from the opinion of the experts and a large number of indicators in theoretical foundations, and reliability of the questionnaire as shown in Table 3 has been determined through calculating the Cronbach $\alpha$ which indicates remarkable reliability. For data analysis, the obtained data were initially coded and entered into SPSS and then descriptive statistics and inferential statistics were performed. To test the hypothesis, considering that questions were drawn up in two parts, in the first section of the questionnaire, the Chisquare and Cramer's V-test, and in the second section of the questionnaire the two independent sample $t$ test was used. In this research, housing sustainability was divided into 3 main dimensions of physical-environmental, physical-economic, and physical-social. Sustainable housing in terms of physio-environmental dimension is a housing that is built by durable and recyclable native materials suitable to the climate, and by employing appropriate technology would have suitable strength and security. Table 4 presents the criteria and operational indicators of the physio-environmental sustainability of housing.
Also, sustainable housing in terms of physical-economic is a type of housing that is commensurate with the economic conditions of its residents. Table 5 presents the operational criteria and indicators for physical-economic sustainability of housing. A sustainable housing is one that in terms of its physical-social aspects would be suitable to the culture, conventions, and way of life and traditions of its residents and would help the household stability, social growth and elevating the safety factor of the residents and especially upgrade cultural and psychological serenity of household members. Table 6 presents the criteria and operational indicators of housing physical-social sustainability.

The criteria and explanatory indicators have been studied with regard to rural households residing in the central district of Kabudarahang County. Kabudarahang County is located in a plane with an area of $750 \mathrm{~km}^{2}$, in Hamadan Province. It is bordered by Zanjan Province on the north, Kurdistan Province on the west, Razan County on the East, and Hamadan County on the south. In this research, 10 villages of 5 rural districts of the central area of Kabudarahang County (2 villages from each rural district) were studied through direct questions and answers carried out by the researcher accompanied with the village headman or members of the village council, also by surveying the villages and ensuring that the selected villages contain the two old and new structural textures. Sampling method was stratified random sampling. Also, out of the sample villages' household population, by using Cochran's formula, 300 households were selected as

Table 6. Criteria and operational indicators of rural housing physical-social sustainability

\begin{tabular}{|c|c|c|}
\hline $\begin{array}{l}\text { Sustainability Dimen- } \\
\text { sions }\end{array}$ & Criteria & Indicator \\
\hline \multirow{5}{*}{ Physical-social } & Having facilities & $\begin{array}{l}\text { The amount of infrastructure facilities in the residen- } \\
\text { tial unit } \\
\text { The amount of welfare facilities in the residential unit } \\
\text { The amount of health facilities in the residential unit }\end{array}$ \\
\hline & Access to facilities & $\begin{array}{c}\text { Degree of access to shopping centers in the rural com- } \\
\text { munity } \\
\text { Degree of access to centers of public transportation } \\
\text { Degree of access to education centers } \\
\text { Degree of access to health centers } \\
\text { Degree of access to cultural, religious centers (library, } \\
\text { mosque) }\end{array}$ \\
\hline & Density & $\begin{array}{c}\text { The suitable scale by which the housing unit occupies } \\
\text { infrastructure } \\
\text { Household density in housing unit } \\
\text { Room density in housing unit } \\
\text { Density of persons per room in the housing unit }\end{array}$ \\
\hline & $\begin{array}{l}\text { The impact of rural housing unit in the } \\
\text { production of waste }\end{array}$ & $\begin{array}{l}\text { Collection and disposal of waste } \\
\text { The use of sewage disposal system }\end{array}$ \\
\hline & Satisfaction & Level of satisfaction of housing \\
\hline
\end{tabular}



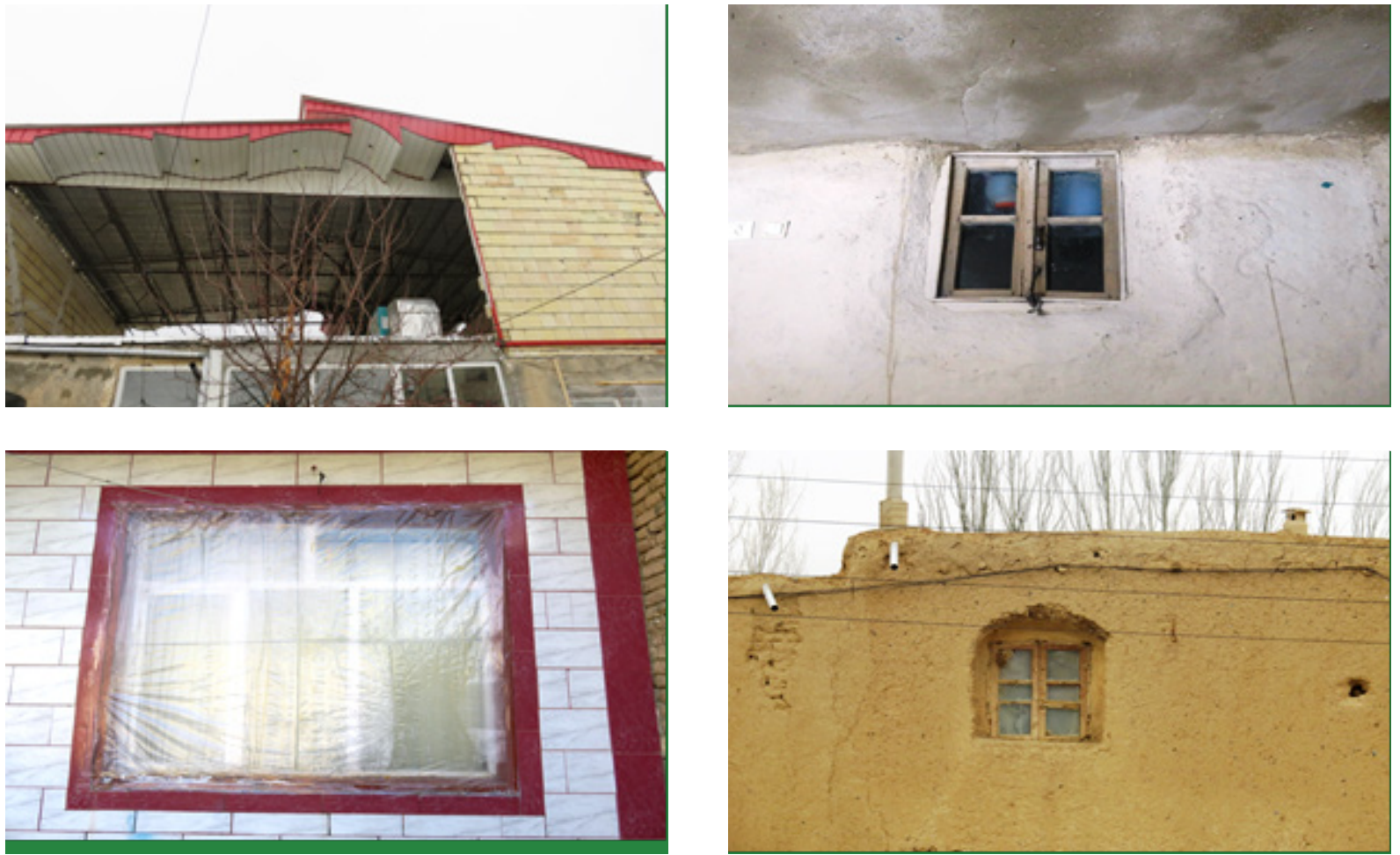

- JSRD

Figure 6. Observance of minimization and miniaturization of windows and openings in housing units of the old texture for saving energy

analysis unit. Out of them, 150 households in the old texture and 150 households in the new texture were studied.

\section{Findings}

This section contains two parts of descriptive and analytical. First, in the descriptive part, by using meth- ods of descriptive statistics, descriptive results were yielded from the questionnaires' findings, and in the second part, by using the methods of inferential statistics we analyzed and tested the hypothesis and terms of the relationships between the variables based on the research hypothesis, and eventually a summary and conclusion were provided.

Table 7. The descriptive findings of observance of physical-environmental criteria in housing construction in the old and new texture

\begin{tabular}{|c|c|c|c|}
\hline \multirow{2}{*}{ Dimensions } & \multirow{2}{*}{ Indicator } & \multicolumn{2}{|c|}{ Texture } \\
\hline & & Old & New \\
\hline \multirow{7}{*}{ Physical-environmental } & $\begin{array}{c}\text { Use of local materials in accordance with geographical conditions of the } \\
\text { region }\end{array}$ & 3.21 & 2.98 \\
\hline & Effect of residential textures of villages on saving energy & 4.38 & 1.66 \\
\hline & The architectural impact of housing units on saving energy & 3.00 & 3.26 \\
\hline & The impact of rural housing units in the destruction of natural resources & 1.64 & 4.07 \\
\hline & Durability of materials used in housing construction & 1.43 & 4.07 \\
\hline & Durability of housing unit structures & 1.25 & 1.70 \\
\hline & Old texture & \multicolumn{2}{|c|}{ New texture } \\
\hline
\end{tabular}



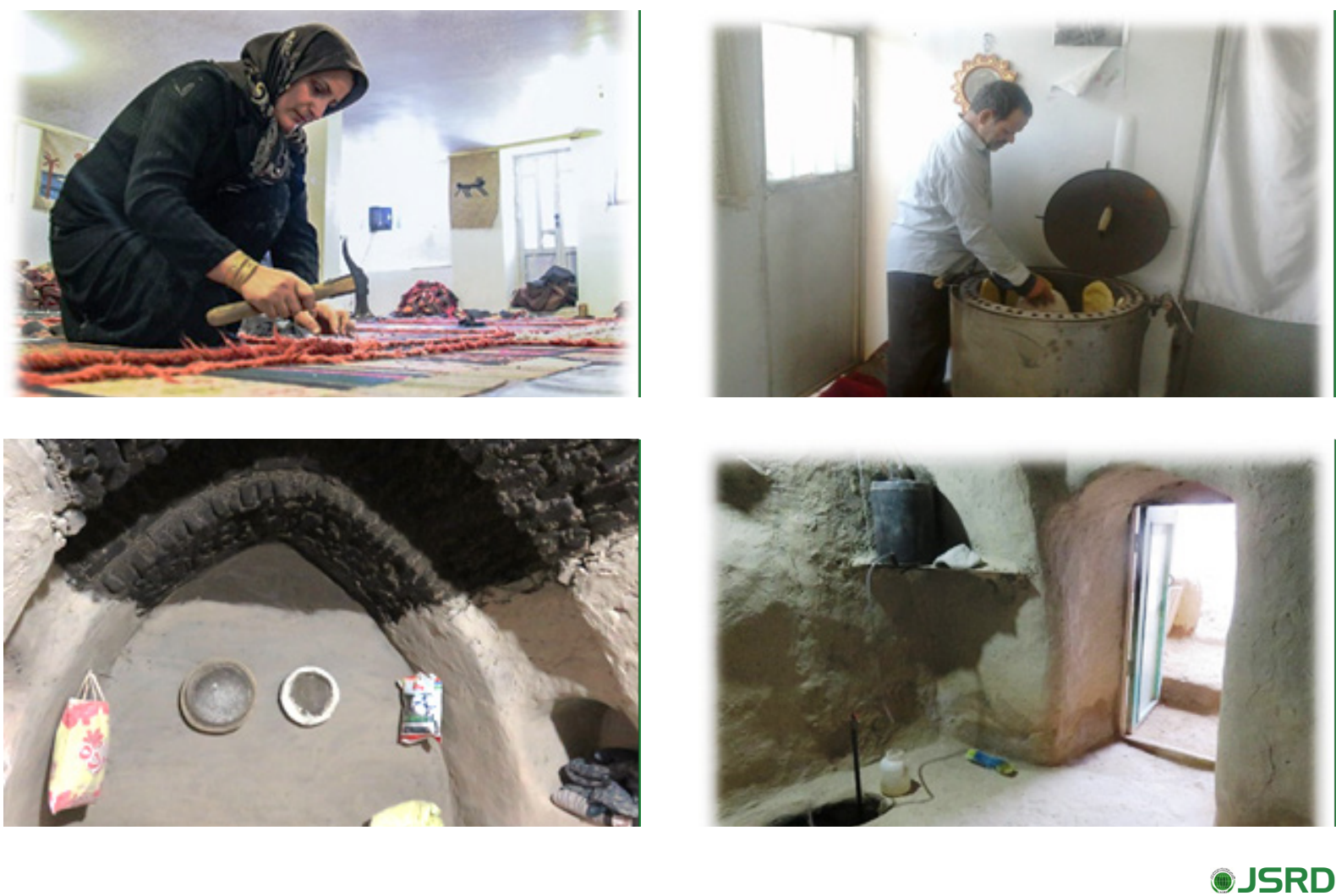

Figure 7. Observance of minimization and miniaturization of windows and openings in housing units of the old texture for saving energy

Descriptive findings that explain the individual characteristics of the respondents indicated that $94 \%$ of the respondents in the old texture and $97 \%$ of the respondents in the new texture were men. Also, $40 \%$ of the respondents in the old texture and $60 \%$ of the respondents in the new texture were between 20 and 40 years old. As regards the educational level, more than $50 \%$ of them had education of the ninth grade or higher. As it is shown in Table 7 and Figure 6, the descriptive values found in the explanatory items of physical-environmental sustainability dimension indicate that the sustainability level of traditional and old housings in the old structural texture is more than the new housings in the new texture.

As it is shown in Table 8 and Figure 7, the descriptive findings in most explanatory items of physical-economic sustainability dimension indicate that the traditional housings in the old texture have more sustainability compared to new housings in the new texture.

Also, it is shown in Table 9 and Figure 8, the descriptive findings of the most explanatory items of the phys-

Table 8. Descriptive findings of observance of physical-economic criteria in housing construction in the old and new texture

\begin{tabular}{lccc}
\hline \multirow{2}{*}{ Dimensions } & Indicator & \multicolumn{2}{c}{ Texture } \\
\cline { 3 - 4 } & Current costs of housing & Old & New \\
\hline Physical-economic & Fixed costs of housing & 3.19 & 4.10 \\
& Use of financial aids & 2.95 & 3.39 \\
& Housing supply and demand & 1.81 & 3.62 \\
\hline
\end{tabular}


Table 9. Descriptive findings of observance of physical-social criteria in housing construction in the old and new texture

\begin{tabular}{|c|c|c|c|}
\hline \multirow{2}{*}{ Dimensions } & \multirow{2}{*}{ Indicator } & \multicolumn{2}{|c|}{ Texture } \\
\hline & & Old & New \\
\hline \multirow{5}{*}{ Physical-social } & Amount of facilities in Housing unit & 3.88 & 3.00 \\
\hline & Degree of access to facilities & 3.76 & 3.61 \\
\hline & Amount of space in Housing unit & 4.26 & 3.84 \\
\hline & The impact of housing units in production of waste materials & 2.83 & 3. 56 \\
\hline & Level of satisfaction from the housing unit & 2.15 & 1.81 \\
\hline
\end{tabular}

ical-social sustainability dimension, indicate that the traditional and old housing units in the old texture have more sustainability compared to the new housing units in the new texture.

As it could be observed in Table 10, the descriptive statistics that have been obtained from the households in the old and new textures indicate that with regard to the physical-environmental dimension, on average, the old texture with the value of 2.48 demonstrates more environmental sustainability compared to the new texture. Also, with regard to all criteria of physical-economic dimension, the old texture presents higher values (indicators are of cost variety type and the lower value is the criterion) and on average the old texture with the value of 2.87 shows more economic sustainability compared to the new texture. With regard to the physical-social dimension, on average, the old texture with the value of 3.34 shows more social sustainability compared to the new texture.

\section{Discussion}

Considering the research hypothesis, to assess the items of a binary subject that in all dimensions comprised question with yes-no options, the Chi-square test was used in a way that the two old and new textures were compared and subjected to the comparative test. In this test, as the significant value was smaller than 0.05 , the $\mathrm{H}_{0}$, indicating the independence of row and columns variables, was rejected, i.e., a significant difference is present between the observed variables and predicted ones. Thus, there is a significant difference between housing sustainability level in the old and new textures.

With regard to questions, with the interval-ratio scale, as it is shown in Table 11, for data analysis, the t test was used for the two independent groups. In this test, $\mathrm{H}_{0}$ hypothesis test indicates no significant difference in housing sustainability between old and new textures, and the $\mathrm{H}_{1}$ indicates the significant difference of housing sustainability between old and new textures. As it can be seen, the amount of calculated $t$ in each of the three dimensions (physical-environmental, physical-economic, physical-social) is smaller than 0.05 . Therefore, the difference between housing sustainability between two groups (old and new textures) can be accepted. It can also be inferred that the degree of housing sustainability with regard to the physical-environmental, physical-economic, and physical-social dimensions in housing units located in the old texture is more than the new housing units in the new texture.
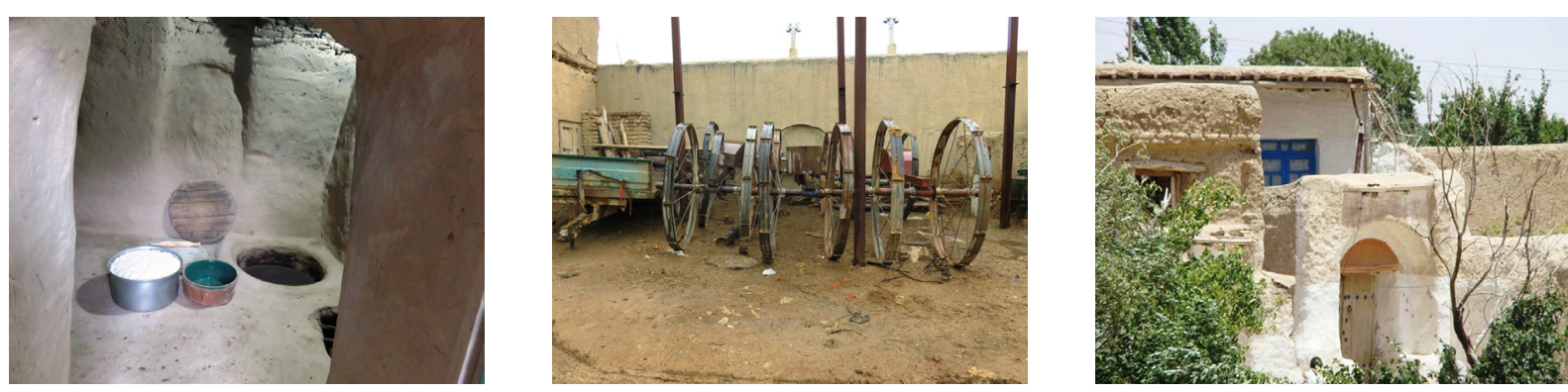

Figure 8. Observance of social criteria of housing construction in the old texture housing units 
Table 10. Housing units sustainability level in the old and new textures

\begin{tabular}{ccc}
\hline Sustainability Dimensions & Old Texture & New Texture \\
\hline Physical-environmental & 2.48 & 2.23 \\
Physical-economic & 2.87 & 2.93 \\
Physical-social & 3.34 & 3.20 \\
\hline
\end{tabular}

Table 11. The t-test results of the difference between housing sustainability between old and new textures

- JSRD

\begin{tabular}{ccccccc}
\hline & & & & \multicolumn{2}{c}{ Degree of Sustainability } \\
\cline { 4 - 7 } Sustainability Dimensions & Sig. Level & $\mathbf{t}$ & df & & Old & New \\
\hline Physical-environmental & 0.048 & -29.545 & 298 & 2.48 & 2.23 \\
Physical-economic & 0.028 & -7.377 & 298 & 2.87 & 2.93 \\
Physical-social & 0.043 & 15.670 & 298 & 3.34 & 3.20 \\
\hline
\end{tabular}

Descriptive and inferential statistical examinations indicate that regarding physical-environmental dimension, the old texture has a higher average value and more sustainability level compared to the new texture. In examining the physical-environmental indicators in the old texture, the highest mean value was related to the impact of the housing unit texture in saving energy and lowest mean value was related to the durability of the structure.

In examining the physical-economic indicators in the old texture, the highest mean value relates to the amount of space allocated in the housing unit for earning livelihood, and the lowest mean value is related to the amount of using financial aids. Also, results in the physical-social dimension indicate a better sustainability level of the old texture compared to the new one. In examining the physical-social indicators in the old texture, the highest mean value relates to the level the housing unit enjoyed various spaces and the lowest mean value was related to the degree of satisfaction toward the housing, which despite having higher sustainability, showed a lower level of satisfaction among the respondents and deserves contemplation and further study. Nevertheless, in examining the indicators related to the physical-social dimension of housing sustainability, the old texture showed a higher degree of sustainability compared to the new one. Considering the obtained results, the following solutions are suggested to improve housing conditions in the villages under study:

- In the new housing constructions, native methods of construction can be employed and refrain should be made from emphasis on mimetic architectural models and uniformity in all regions, such architectural models that have very low compatibility or in some instances, incompatibility with the environmental conditions in rural areas.

- Studies indicate that in some cases, such as materials' durability, framework, and so on, the new texture has a better status compared to the old one. Therefore, in housing construction process towards the highest possible sustainability, a combination of both methods (old and new) could be effective.

- Considering the low durability of housing materials in the old texture, building safe and secure framework of the rural environment and housing based on Iranian architectural model by participation of the people, government, and public foundations, as well as using specialists accompanied with using native and local human resources in rural housing construction can be effective and improves the satisfaction level of residents in housing units with traditional model.

\section{Acknowledgements}

This research did not receive any specific grant from funding agencies in the public, commercial, or not-forprofit sectors.

\section{Conflict of Interest}

The authors declared no conflict of interests. 


\section{References}

Andrade, J., Martin, A., \& Rodriguez, A. (2015). Sustainable Incremental Rural Housing: Case study in Cuetzalan, Puebla, Mexico). Rämistrasse: ETH Zürich.

Azizi, M. (2007). [Housing indicators station in planning process (Persian)]. Honar-ha-ye-Ziba, 17(17).

Berry, J. W. (1980). Cultural ecology and individual behavior. Environment and Culture, 83-106. doi: 10.1007/978-1-4899-0451-5_4

Boran, J. (2010). Towards greener pastures sustainable housing options for America's rural poor. Paper presented at the Environmental Studies Senior Research Seminar, Massachusetts, U.S.A., 1 November 2010.

Bossel, H. (1999). Indicators for sustainable development: Theory, method, applications. Winnipeg: International Institute for Sustainable Development.

Brouwer, C. (2004). Sustainable development: Exploring the contradictions. New York: Methuen.

Building Maintenance Unit. (2010). Sustainable buildings and construction in Africa. Zimbabwe: Federal Ministry for the Environment, Nature Conservation and Nuclear Safety.

Choguill, C. L. (2007). The search for policies to support sustainable housing. Habitat International, 31(1), 143-9. doi: 10.1016/j.habitatint.2006.12.001

Darabi, H. (2009). [A review of physical planning theories (Persian)]. Tehran: Rural Housing Foundation Publications.

Dix, G. (1995). The place of shelter in national development. In S. D Romaya, \& G. H. Franklin, (Eds.), Shelter, Services and the Urban Poor (pp. 1-10). Cardiff: University of Wales Institute of Science and Technology.

Edwards, B., \& Turent, D. (2000). Sustainable housing: Principles and practice. London: E \& FN Spon.

Government of Bangladesh. (1997). The fifth five year plan (1997-2002). Dhaka: Planning Commission, Ministry of Planning.

Islamic Revolution Housing Foundation. (2001). [Role of rural housing in creating jobs, calculating the surplus capacity of rural housing job creation (Persian)]. Tehran: Islamic Revolution Housing Foundation.

Karimi, A. (1990). [A brief examination of various theories regarding the general shape of traditional and rural housing (Persian)] Geographical Research Quarterly, 1(1), 143-4.

Khodadadi, P., Muhammadnejad, A. (2010). [The role of valuable rural textures in development of tourism (Case study: Javaher Deh villages, Ramsar) (Persian)]. Journal of Geographical Space Tourism, 2(8), 59-79.

Korten, D. C. (2005). Sustainable development: Conventional versus emergent alternative wisdom. Development, 48(1), 65-69. doi: 10.1057/palgrave.development.1100105

Lutfi, H., Ahmadi, A., \& Hssanzadeh Farjoud, D. (2009). [Indicators and components needed in rural housing policy making in Iran (Persian)]. Amayesh, 2(7), 105-28.

Madhumathi, A., Vishnupriya, J., \& Vignesh, S. (2014). Sustainability of traditional rural mud houses in Tamilnadu, India: An analysis related to thermal comfort. Journal of Multidisciplinary Engineering Science and Technology, 1(5), 302-311.
McKeogh, S. (2005). Rural housing and sustainable community development in the west of Ireland: A case study of County Mayo (MA thesis) Galway: Galway-Mayo Institute of Technology.

Mukhber, A. (1984). [Social dimensions of housing, social - economical documents center translation (Persian)]. Tehran: Managment and Planning Organization Pub.

Musavi, M., Hekmatnia, H. (2006). [Application of model in geography by emphasis on urban and regional planning (Persian)]. Tehran: Elm-e Novin Publications.

Pourmohammadi, M. R. (2015). [Planning for housing (Persian)]. Tehran: The Organization for Researching and Composing University Textbooks in Humanities.

Pugliese, P. (2002). Organic farming and sustainable rural development; A manifested and promising governance in sociologic ruralist. Belfast: European Society for Rural Sociology.

Rezvani, M., Karimi, S. H., Nazari, V. (2015). [Assessment of rural housing development policies in the state development plans, with approach toward sustainable development (Persian)]. Paper presented at The National Conference on Sustainable Rural Development in The $6^{\text {th }}$ Development Program, Tehran, Iran, 4 February 2015.

Rezvani, M., Nazari, V., Khorasani, M. (2010). [Concepts and terminology of rural planning and development (Persian)]. Tehran: University of Tehran Pub.

Roknodin Eftekhari, A., Badri, S. A., Sajayi Gheydari, H., \& Soori, R. (2015). [Foundations of the theory of physical planning in rural areas (Persian)]. Tehran: Islamic Revolution Housing Foundation Pub.

Saeedi, A. (1998). [Sustainable development and transient state of rural development (Persian)]. Housing And Rural Environment, 87 $17-22$.

Sartipipour, M. (2005). [Pathology of rural architecture, moving toward desirable residential place (Persian)]. Tehran: Shahidi.

Sartipipour, M. (2011). [Rural housing in development plans (Persian)]. Fine Arts Journal, 27, 47-56.

Shayan, M., Barghi, H., \& Agha Amrayie, A. (2014). Studying indicators of sustainable housing in rural areas (Case study: Villages of Zarrindasht). Bulletin of Environment, Pharmacology and Life Sciences, 3(11), 187-93.

Toyobo, A. E., Muili, A. B., \& Adetunji, M. A. (2014). The relevance of infrastructural facilities to rural housing development in lagelu local government, Oyo State, Nigeria. International NGO Journal, 9(3), 29-30. 